\title{
Influence of Temperature and Salinity on Food Conversion and Growth of Different Nereis Species (Polychaeta, Annelida)*
}

\author{
H.-G. Neuhoff \\ Institut für Meereskunde an der Universität Kiel, Düsternbrooker Weg 20, D-2300 Kiel 1, Federal Republic of Germany
}

\begin{abstract}
Feeding experiments in 15 and $30 \%$ salinity reveal similar food conversion rates of Nereis succinea and $N$ diversicolor at high temperature $\left(15^{\circ} \mathrm{C}\right)$. At low temperature $\left(5^{\circ} \mathrm{C}\right)$ food conversion of $N$. diversicolor is more efficient. A salinity increase from 15 to $30 \% \mathrm{~S}$ facilitates better food conversion in both species leading to an increased energy content (exception: $N$. succinea at $5{ }^{\circ} \mathrm{C}$ and $30 \%$ S). $N$. diversicolor exhibits better food conversion at low temperature, generally higher production rates, lower gross energy demand for production and a lower maintenance metabolism at $15 \% \mathrm{~S}$ in comparison with $N$. succinea. This suggests that $N$. diversicolor is better fitted to the specific environmental conditions of the Baltic Sea than $N$. succinea. A comparison of assimilation efficiencies and gross growth efficiencies of different species showed an increase in the sequence $N$. succinea, $N$. diversicolor and $N$. virens.
\end{abstract}

\section{INTRODUCTION}

Nereis species are known to serve as food organisms, for example for cod and plaice (Kinne, 1954; Muus, 1967). Some of these species are stenohaline; others are euryhaline and show quite different salinity preferences ranging from fresh water to marine environments (Smith, 1970). Nereis species of Kiel Bay prefer shallow waters and, therefore, are exposed to seasonally changing temperatures. Both temperature and salinity are known to influence functional and structural properties (Kinne, 1964, 1970b, 1971b). They might affect body components and growth parameters as well and cause qualitative and quantitative changes. To quantify these changes, individuals of the omnivorous $N$. diversicolor and the detritus-feeding $N$. succinea from the same habitat in Kiel harbour (Baltic Sea) were fed under various temperature and salinity combinations. A comparison with data from the literature for the omnivorous $N$. virens should permit the evaluation of species-specific differences of productivity parameters and ecological pretensions.

\section{MATERIAL AND METHODS}

The two examined Nereis species are free-living and tolerate a wide range from euhaline to oligohaline salinities, temporarily even fresh water (HartmannSchroeder, 1971). In Kiel harbour, N. succinea is abundant in a sapropel habitat at a depth of $5 \mathrm{~m}$ (near Bellevue Bridge) feeding on substrate and detritus particles. The omnivorous $N$. diversicolor is also found in this habitat but prefers a shallower sand biotope down to $2 \mathrm{~m}$ depth (for feeding preferences consult Goerke, 1966, 1971a; and Hartmann-Schroeder, 1971).

During the feeding experiments the worms were kept in a darkened box containing $25 \mathrm{l}$ sea water, allowing at least $1 \mathrm{l}$ per animal. At a pumping rate of $180 \mathrm{I} \mathrm{h}^{-1}$ the sea water was cleaned by filtering through a charcoal filter. In addition, the whole water content was renewed once a week. Each worm lived in a Petri dish of 5-cm diameter and two opposing chimney-like glass tubes $7.5 \mathrm{~cm}$ long with inner diameters varying from 3 to $7 \mathrm{~mm}$ according to the animal's size (Fig. 1). Worms which had left their dish were identified by distinguishing marks and weight. Animals were fed once a day but only when they had eaten up their last ration. Food portions ranged from 0.05 to $0.2 \mathrm{~g}_{\mathrm{ww}}$ and were placed into the Petri dishes.

For experiments under marine conditions, the worms were gradually adapted to $30 \% \mathrm{~S}$, whereby the Baltic-

\footnotetext{
- Publication No. 246 of the Joint Research Programme at Kiel University 'Interaction Sea - Sea Bottom' (Sonderforschungsbereich 95 der Deutschen Forschungsgemeinschaft).
} 


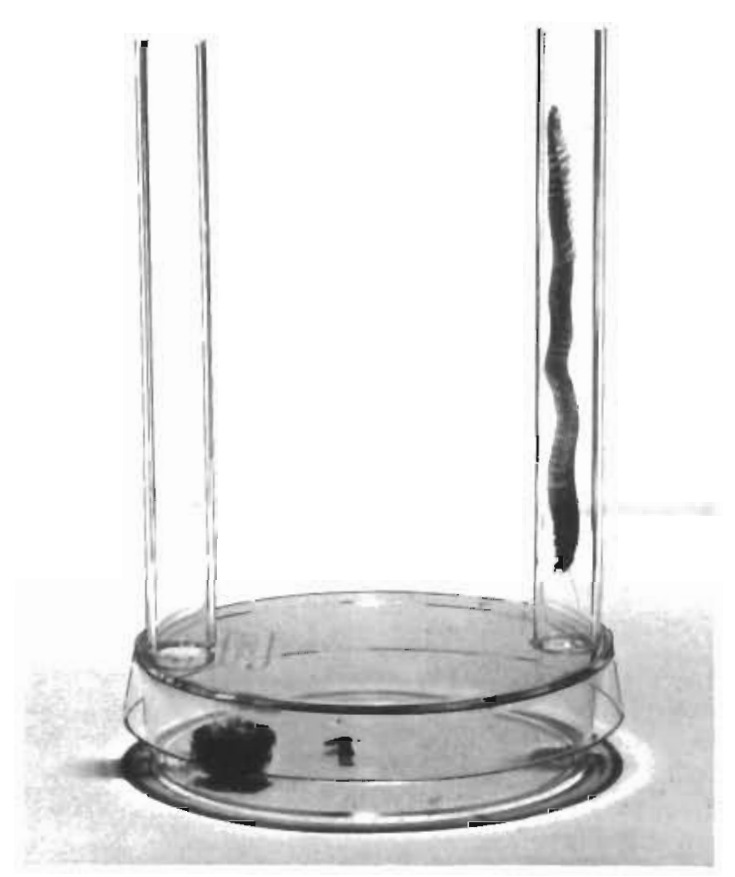

Fig. 1. Nereis succinea. A test individual in its housing. Petri dish (Polystyrene) $\varnothing 5 \mathrm{~cm}$; glass tubes $\varnothing 3-7 \mathrm{~mm}$, depending on worm size; food cube

Sea salinity was increased in $3 \%$ steps over a period of 10 days. For the same period the animals were not fed in order to clear their gut. The subsequent feeding period lasted for 28 days.

The Petri dishes of two worms per experiment were cleaned every second day, collecting food residues, faeces and the thin mucous layer with which inhabited parts of the housings were often coated. The wastes were deep frozen $\left(-28^{\circ} \mathrm{C}\right)$ for later analysis. Their total energy value was subtracted from the total energy value of the food consumed, thus revealing the value of the food assimilated. Due to the normally inseparable mucous component, this value can be slightly underestimated.
Biochemical criteria like glycogen, lipid and protein contents were determined according to methods of Lowry et al. (1951), Zöllner and Kirsch (1962) and Handel (1965). Energy contents were determined according to Phillipson (1964) and a manual of Gentry Instruments. For details see Neuhoff (1979).

The food used in these experiments was composed of 1 part Agar Agar, 20 parts freeze-dried and ground Mytilus tissue and 100 parts water. The preparation was done as follows: Water was heated until boiling and Agar Agar added. While stirring, the solution was cooled to $60^{\circ} \mathrm{C}$. The lyophilized and ground Mytilus tissue was then added. While stirring, the pulp was cooled to $30^{\circ} \mathrm{C}$ and then poured into Petri dishes.

\section{RESULTS}

Results of feeding experiments whether they refer to body components or to growth responses must be comparable. For this reason results of this study are normally given for a standard worm containing $0.0962 \mathrm{~g}$ organic substance (= ash free dry weight). This represents the mean value of 290 Nereis succinea derived from samples collected during 18 successive months. Where necessary, values were also calculated for a standard worm containing $0.015 \mathrm{~g}$ organic substance.

All experiments were preceded by a $10 \mathrm{~d}$ period without feeding. This was necessary in order to clear the animals' gut and to adapt them to a higher salinity $(30 \% \mathrm{~S})$ where required. Thus all individuals had equal starting conditions at the beginning of an experiment. During this time the worms had to maintain their metabolism at the expense of their own body substance. When exposed to habitat salinity $(15 \% \mathrm{~S}$, $15^{\circ} \mathrm{C}$ ). Nereis diversicolor showed a smaller energy loss during this starvation period than $N$. succinea (Table 1). When in the course of this period the worms were adapted to $30 \% \mathrm{~S}$ their energy loss was generally higher, with energy loss of $N$. diversicolor surpassing that of $N$. succinea.

Table 1. Nereis succinea and $N$. diversicolor. Energy requirements for maintenance metabolism of standard worms $10.0962 \mathrm{~g}$ organic substance) during starvation period of $10 \mathrm{~d}$ at $15{ }^{\circ} \mathrm{C}$ and 15 or $30 \% \mathrm{~S}$

\begin{tabular}{|c|c|c|c|c|c|}
\hline $\begin{array}{l}\text { Salinity } \\
\qquad \%(\%)\end{array}$ & $\begin{array}{l}\text { WW' } \\
(g)\end{array}$ & $\begin{array}{c}\text { Loss of } \\
\text { body substance } \\
(\%)\end{array}$ & $\begin{array}{c}\text { WW * } \\
\text { (g) }\end{array}$ & $\begin{array}{l}\text { Energy loss } \\
\qquad(\mathrm{J} / \mathrm{d})\end{array}$ & $\begin{array}{c}\text { Additional } \\
\text { energy loss } \\
(\mathrm{J} / \mathrm{d})\end{array}$ \\
\hline \multicolumn{6}{|l|}{ N. succinea } \\
\hline 15 & 0.7273 & -20.7 & 0.5767 & 41.5 & \\
\hline 30 & 0.7273 & -31.4 & 0.4989 & 62.8 & 21.3 \\
\hline \multicolumn{6}{|l|}{$N$ diversicolor } \\
\hline 15 & 0.6789 & -11.4 & 0.6015 & 24.3 & \\
\hline 30 & 0.6789 & -35.2 & 0.4399 & 75.0 & 50.7 \\
\hline
\end{tabular}




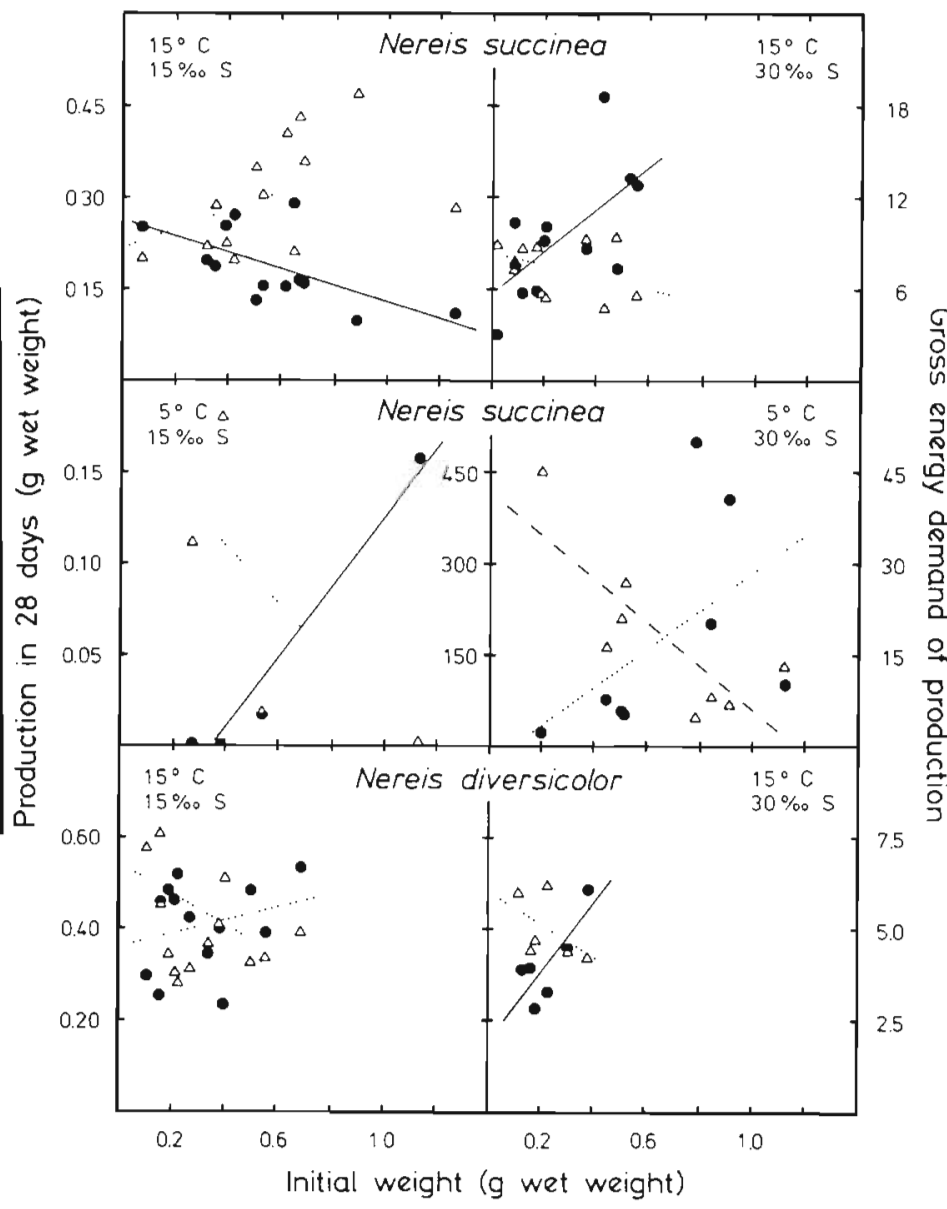

Growth parameters are calculated for a standard worm containing $0.0962 \mathrm{~g}$ organic substance (Table 2). In addition to the 28 - $d$ production rate and the gross energy demand for production $(C / P)$, both presented in Figure 2, they give the net energy demand of production $(A / P)$, gross and net growth efficiency $(P / C$ and $P /$ $A)$ as well as assimilation efficiency $(A / C)$ in percent. The latter three show what percentage of the consumed (or assimilated) food is used for production and what percentage of the consumed food is assimilated.

In standard experiments with Nereis succinea $\left(15^{\circ} \mathrm{C}\right.$, 15 or $30 \% \mathrm{~S}$ ) the worms showed two distinct reaction types: fast- and slowly-growing animals (Type A and B) were clearly discernible by a discrimination analysis (Table 2). Both types showed decreasing production rates with increasing worm weight at $15 \% \mathrm{~S}$. The gross energy demand for production $(C / P)$, however, increased, thus indicating that older worms convert food less effectively. The 30\%-salinity experiment revealed inverse relations: production rate increased

Fig. 2. Nereis succinea (Type A) and $N$. diversicolor. Size dependence of production rate $(P)$ and gross energy demand for production $(C / P)$. Individuals were fed for $28 \mathrm{~d}$ at different temperatures and salinities. - Regression of production rate on initial weight; values correlated at $\leq 5 \%$ significance. Regression of production rate on initial weight; values not correlated. --- Regression of gross energy demand of production on initial weight; values correlated at $\leq 5 \%$ significance. Regression of gross energy demand of production on initial weight; values not correlated

Table 2. Nereis succinea and $N$. diversicolor. Growth parameters of standard worms after feeding period of $28 \mathrm{~d}$ under different abiotic conditions. $P$ : production rate $L_{i}$ : rate of substance loss; $C / P$ : gross energy demand of production; $A / P$ : net energy demand of production; $P / C$ : gross growth efficiency; $P / A$ : net growth efficiency; $A / C$ : assimilation efficiency

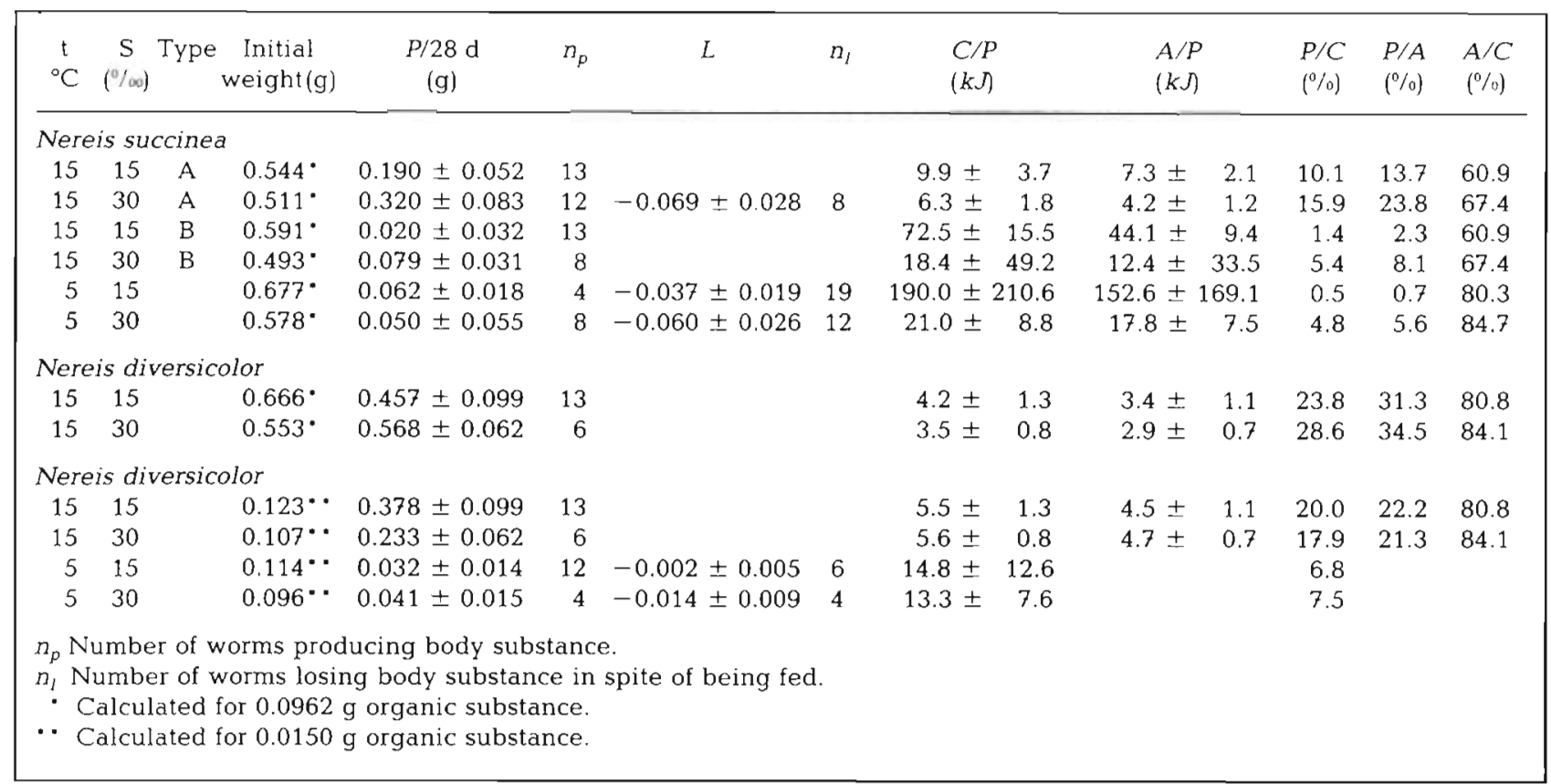


with rising initial weight and the ratio $C / P$ decreased. In all four cases initial weight and production rate were correlated on a $5 \%$ level of significance.

High salinity not only caused an inversion of the size dependence of the production rate but also a lower gross energy demand for production $(C / P)$, a higher gross growth efficiency $(P / C)$ and assimilation efficiency $(A / C)$, as shown by a comparison of corresponding reaction types at $15^{\circ} \mathrm{C}$ and 15 or $30 \% \mathrm{~S}$ (Table 2 ).

Low temperature experiments with Nereis succinea $\left(5{ }^{\circ} \mathrm{C}_{i} 15\right.$ or $\left.30 \% \mathrm{~S}\right)$ were first of all marked by numerous worms which lost weight although they were fed (Table 2). Far more worms were able to grow at a salinity of $30 \%$ than at $15 \%$ S. Both experiments documented increasing production rates with increasing initial weight (Fig. 2). Values for standard worms were of similarly low magnitude (Table 2). The energy demand for production decreased with body weight. In contrast to a similar magnitude of production rates in both experiments a standard worm at $15 \% \mathrm{~S}$ needed nine times more energy for production than at $30 \% \mathrm{~S}$. The observed substance losses of fed worms were bigher in the high salinity experiment. They were lower, however, than comparable values at $15^{\circ} \mathrm{C}$ (Table 2).

Growth reactions of Nereis diversicolor were examined at temperatures of $5{ }^{\circ} \mathrm{C}$ and $15^{\circ} \mathrm{C}$ and salinities of 15 and $30 \% \mathrm{~S}$. In all cases production rates increased, and gross energy demands for production decreased with increasing initial weight (Fig. 2). However, the values showed a very high variability so that a statistical correlation between body size and the growth parameters investigated was only found for the production rate at $15{ }^{\circ} \mathrm{C}, 30 \% \mathrm{~S}(5 \%$ level of significance)

Growth parameters of $5{ }^{\circ} \mathrm{C}$ experiments had to be calculated for a smaller standard worm with $0.015 \mathrm{~g}$ organic substance. In the case of these experiments wastes were too small for determining assimilation values. At $5{ }^{\circ} \mathrm{C}$ the gross energy demand for production $(C / P)$ was about three times higher than at $15^{\circ} \mathrm{C}$. Correspondingly, a far smaller production rate was found at $5{ }^{\circ} \mathrm{C}$. A higher sainity of $30 \%$ produced higher growth rates regardless of whether temperature was high or low.

Production rates of Nereis diversicolor at $15^{\circ} \mathrm{C}$ and in both salinities were about twice as high as those of $N$. succinea under the same conditions. Correspondingly, the gross energy demand of $N$. diversicolor for production $(C / P)$ was lower. In contrast to $N$. succinea, most $N$. diversicolor were able to grow at $5{ }^{\circ} \mathrm{C}$.

Some difficulties, often reducing the number of evaluable worms, arose in metamorphosing individuals or worms with quite variable response patterns ranging from high (Type A) over low (Type B) to negative growth rates, or due to mortality and handling damages incurred during experiments.

Size dependence of body components of individuals of a Nereis succinea field population is shown in Figure 3 and can be described by regression lines. Glycogen and lipid contents of in situ worms normally increased, while the protein content decreased with increasing body size. Energy content often seemed to be size independent.

Low temperature influenced feeding in Nereis succinea (Fig. 4, worms fed for 28 days) in the following way: The glycogen and lipid levels were lower at $5^{\circ} \mathrm{C}$ than at $15^{\circ} \mathrm{C}$. Corresponding contents of a field individual, however, reached higher values at the lower

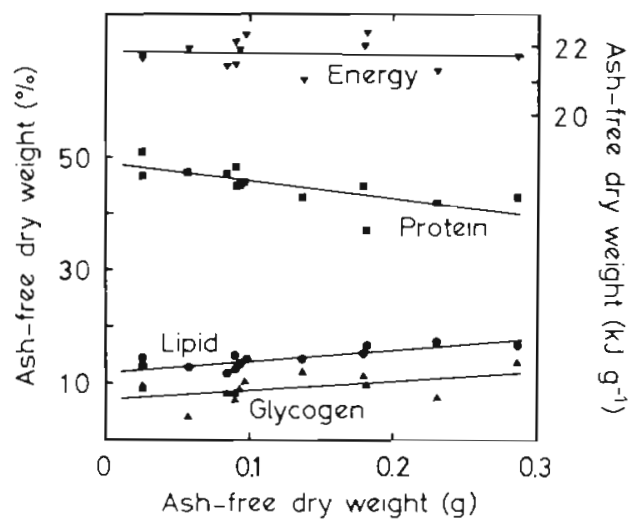

Fig. 3. Nereis succinea. Size dependence of some body parameters

temperature. Protein contents were similar at both temperatures with slightly elevated values at $5{ }^{\circ} \mathrm{C}$. Low temperature experiments produced lower energy contents which were very similar to those of field individuals.

In addition to temperature, food conversion of Nereis succinea was influenced by salinity. Protein contents were higher at $30 \% \mathrm{~S}$ regardless of whether experimental temperatures were $5^{\circ}$ or $15^{\circ} \mathrm{C}$. Energy content showed salinity-elevated values at $15^{\circ} \mathrm{C}$. Glycogen and lipid contents were generally lower than those at $15 \% \mathrm{~S}$ (Fig. 4).

Experiments under standard conditions $\left(15^{\circ} \mathrm{C} ; 15\right.$ or $30 \%$ S) were also carried out with Nereis diversicolor (Fig. 4). Salinity influence on food conversion was largely the same as for $N$. succinea. In comparison with this species, however, much higher glycogen contents were found while lipid and protein contents showed lower values. Energy levels of both species were very much alike under these conditions.

To compare the results of $5^{\circ} \mathrm{C}$ feeding experiments on Nereis diversicolor with those of other experiments, all values had to be calculated for a standard worm 


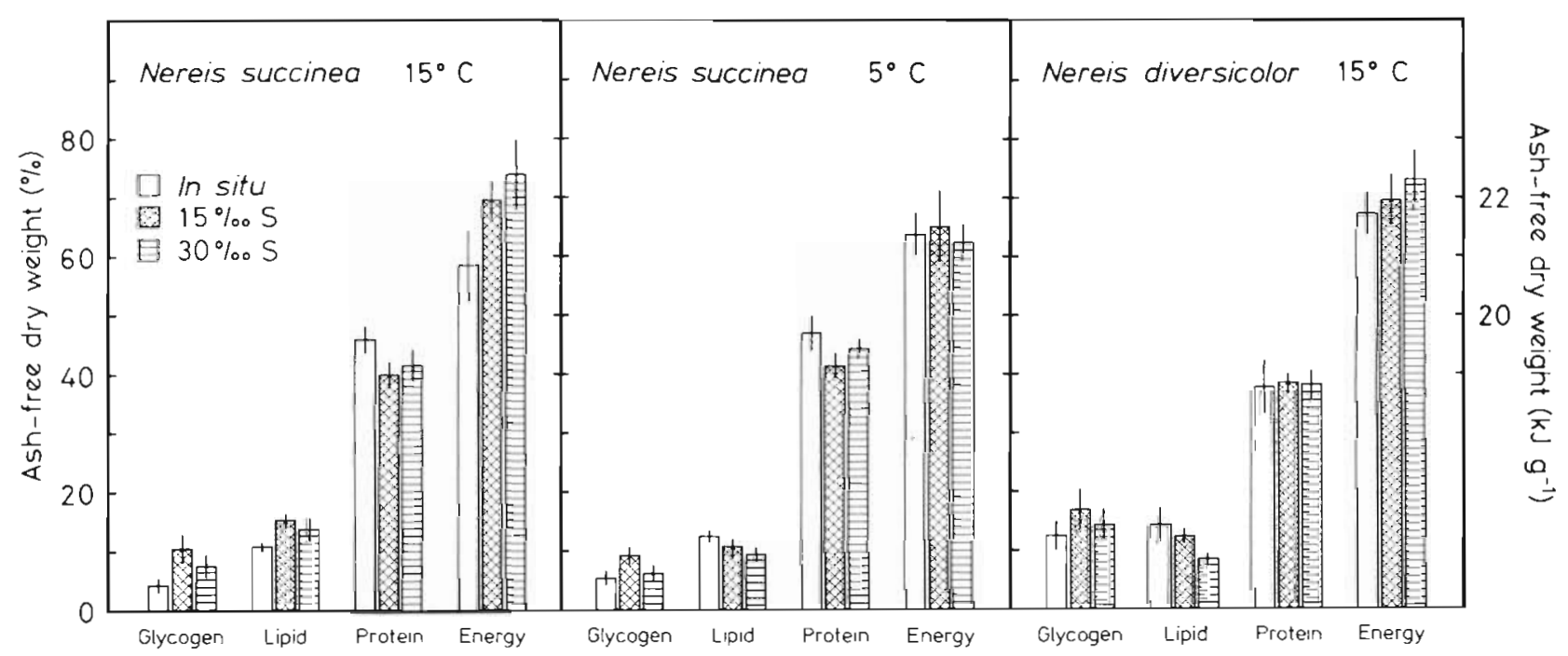

Fig. 4. Nereis succinea and N. diversicolor. Biochemical parameters of standard worms (0.0962 g organic substance) fed for $28 \mathrm{~d}$ at $15^{\circ} \mathrm{C}$ in different salinities. Values calculated via regression equation; vertical bars: standard error of the estimate ( $\left.s_{y . x}\right)$

containing $0.015 \mathrm{~g}$ organic matter (Table 3) as only small individuals were available for these experiments. Similar to corresponding experiments with $N$. succinea glycogen contents of $N$. diversicolor decreased with decreasing temperature. Lipid, protein and energy contents, however, increased.

Compared with a Nereis succinea worm of the same size $(0.015 \mathrm{~g}$ organic matter), $N$. diversicolor showed higher glycogen and - in contrast to the experiments conducted at $15^{\circ} \mathrm{C}$-also higher lipid and much higher energy levels. Although the standard field animal already showed a relatively high energy level, this value could be increased by feeding in the $30 \% \mathrm{~S}$ experiment irrespective of the low temperature. The corresponding experiment with $N$. succinea showed no similar effect (Table 3).

\section{DISCUSSION}

Changes in environmental conditions, e.g. fluctuations in temperature and salinity, can affect metabolic activities and cause changes in growth rates and chemical composition of marine animals. For reviews consult 'Marine Ecology', Volume I: Kinne, 1970a, b, $1971 \mathrm{a}, \mathrm{b}$.

In this study individuals of Nereis succinea and $N$. diversicolor were fed at different combinations of temperature $\left(5\right.$ and $15{ }^{\circ} \mathrm{C}$ ) and salinity (15 and $30 \% \mathrm{~S}$ ). Growth experiments with $N$. succinea and $N$. diversicolor generally show an inverse size dependence of production rate $(P)$ and gross energy demand for production $(\mathrm{C} / \mathrm{P})$. At $15^{\circ} \mathrm{C}$ and $15 \% \mathrm{~S}$, the production rate of $N$. succinea decreases while the gross energy

Table 3. Nereis diversicolor and $N$. succinea. Biochemical composition of standard worms (containing $0.015 \mathrm{~g}$ organic substance) after a feeding period of $28 \mathrm{~d}$ under different abiotic conditions, dw, af: Dry weight, ash free

\begin{tabular}{|c|c|c|c|c|c|c|}
\hline $\begin{array}{l}\text { Time of } \\
\text { experiment }\end{array}$ & $\begin{array}{c}\mathrm{t} \\
{ }^{\circ} \mathrm{C}\end{array}$ & $\begin{array}{c}\mathrm{S} \\
(\% / 00)\end{array}$ & $\begin{array}{c}\text { Glycogen } \\
(\mathrm{dw}, \mathrm{af} ; \%)\end{array}$ & $\begin{array}{c}\text { Lipid } \\
\left(\mathrm{dw}, \mathrm{af}^{\prime} \% \text { ) }\right.\end{array}$ & $\begin{array}{c}\text { Protein } \\
(\mathrm{dw}, \mathrm{af} ; \%)\end{array}$ & $\begin{array}{c}\text { Energy } \\
\left(\mathrm{dw}, \mathrm{af}_{;} ; k J \mathrm{~g}^{-1}\right)\end{array}$ \\
\hline \multicolumn{7}{|c|}{ Nereis diversicolor } \\
\hline \multirow[t]{3}{*}{ September } & \multicolumn{2}{|c|}{ in situ } & $7.3 \pm 2.6$ & $15.6 \pm 2.9$ & $53.8 \pm 4.5$ & $21.194 \pm 0.367$ \\
\hline & 15 & 15 & $14.4 \pm 3.4$ & $12.9 \pm 1.2$ & $39.2 \pm 1.7$ & $22.203 \pm 0.425$ \\
\hline & 15 & 30 & $9.2 \pm 2.6$ & $8.4 \pm 1.0$ & $41.6 \pm 2.4$ & $21.500 \pm 0.514$ \\
\hline \multirow[t]{3}{*}{ February } & \multicolumn{2}{|c|}{ in situ } & $4.1 \pm 1.0$ & $13.4 \pm 0.5$ & $43.6 \pm 7.7$ & $22.105 \pm 0.339$ \\
\hline & 5 & 15 & $9.6 \pm 1.9$ & $14.5 \pm 1.6$ & $45.5 \pm 3.1$ & $22.180 \pm 0.310$ \\
\hline & 5 & 30 & 5.6 & 14.0 & 44.0 & 22.456 \\
\hline \multicolumn{7}{|c|}{ Nereis succinea } \\
\hline \multirow[t]{3}{*}{ December } & \multicolumn{2}{|c|}{ in situ } & $2.9 \pm 1.3$ & $9.9 \pm 1.1$ & $50.0 \pm 3.0$ & $20.995 \pm 0.361$ \\
\hline & 5 & 15 & $6.8 \pm 1.6$ & $9.0 \pm 1.2$ & $42.8 \pm 2.3$ & $21.385 \pm 0.614$ \\
\hline & 5 & 30 & $4.3 \pm 1.6$ & $6.7 \pm 1.2$ & $48.6 \pm 1.5$ & $20.899 \pm 0.324$ \\
\hline
\end{tabular}


demand for production increases with increasing body size. Small worms show high productivity combined with a low gross energy demand for production. When the temperature is lowered or the salinity increased, inverse relations prevail: The larger worms then exhibit higher productivity values. According to Goerke (1971b), high and low temperature experiments $\left(8^{\circ}\right.$ and $\left.16^{\circ} \mathrm{C}\right)$ with $N$. virens in brackish water $(20 \% \mathrm{~S})$ produced the same response pattern. However, the production rate of $N$. diversicolor, irrespective of temperature and salinity, always increases with body size.

Nereis succinea, $N$. diversicolor (this paper) and $N$. virens (Goerke, 1971b) perform high growth rates at temperatures near $15^{\circ} \mathrm{C}$. At lower temperatures, however, only very small growth rates were found. Accordingly, all three species may reduce or even cease growth during winter.

Feeding experiments with adequate food produce gross and net growth efficiencies increasing in the sequence Nereis succinea, $N$. diversicolor, $N$. virens (Table 4). The values of the latter species are by far the highest. Consequences in nature may be found in regard to differences in final weight. Both $N$. succinea and $N$. diversicolor have a life span of about two years (Dales, 1951; Chambers and Milne, 1975; Neuhoff, 1977). The largest individuals of both species observed in Kiel harbour suggest that a final weight may be reached in the range of $2 \mathrm{~g}_{w w} . N$. virens, with a maximum life span of three years, can reach about $15 \mathrm{~g}_{w w}$ in two years (Kay and Brafield, 1973). Different assimilation efficiencies may be an expression of specific modes of nutrition. The omnivorous $N$. diversicolor and $N$. virens, for instance, show assimilation efficiencies of about $80 \%$, whereas in the detritus-feeding $N$. succinea a range of only $60 \%$ is found (Table 4). Higher assimilation efficiencies of $N$. succinea at $5^{\circ} \mathrm{C}$ may be caused by temperature-induced slower gut passage of the food. The low gross-growth efficiencies found for $N$. virens feeding on biodeposits (Tenore and Gopalan, 1974) suggest an influence of food quality. But even the high-grade food offered by the authors gave poor results, in contrast to the gross-growth efficiency reported by Kay and Brafield (1973).

Some of the growth results (Table 2) reported are characterized by high standard errors of the estimate $\left(s_{y, x}\right)$, e.g. the values of the slowly growing B-Type Nereis succinea, all $5^{\circ} \mathrm{C}$ results, and whenever worms lost weight in spite of being fed. This suggests that either the abiotic conditions were unfavourable or the worms themselves might not have been in a normal, healthy condition.

Feeding experiments with Nereis succinea and $N$. diversicolor at different combinations of temperature and salinity (with the exception of $N$. succinea at $5{ }^{\circ} \mathrm{C}$, $30 \% \mathrm{~S}$ ) always produced higher energy contents than in comparable in situ individuals, thus indicating the suitability of the food supplied.

Low temperature has a far greater effect on Nereis succinea than on $N$. diversicolor. Compared with results at higher temperature $\left(15^{\circ} \mathrm{C}\right) \mathrm{N}$. diversicolor at $5{ }^{\circ} \mathrm{C}$ shows only a reduced glycogen content while lipid values as well as energy levels increase

Table 4. Gross growth efficiency $(P / C)$, net growth efficiency $(P / A)$ and assimilation efficiency $(A / C)$ of three Nereis species

\begin{tabular}{|c|c|c|c|c|c|c|c|c|}
\hline Species & Author & Food & $\stackrel{\mathrm{t}}{\left({ }^{\circ} \mathrm{C}\right)}$ & $\begin{array}{c}S \\
(\%)\end{array}$ & $\begin{array}{l}\text { Size } \\
\left(g_{w w}\right)\end{array}$ & $\begin{array}{l}P / C \\
(\%)\end{array}$ & $\begin{array}{l}P / A \\
(\%)\end{array}$ & $\begin{array}{l}A / C \\
(\%)\end{array}$ \\
\hline N. succinea & 1 & $\begin{array}{l}\text { Mytilus } \\
\text { edulis }\end{array}$ & $\begin{array}{l}15 \\
15\end{array}$ & $\begin{array}{l}15 \\
30\end{array}$ & $\begin{array}{l}0.5 \\
0.5\end{array}$ & $\begin{array}{l}10 \\
16\end{array}$ & $\begin{array}{l}14 \\
24\end{array}$ & $\begin{array}{l}61 \\
67\end{array}$ \\
\hline \multirow[t]{3}{*}{ N. diversicolor } & 1 & $\begin{array}{l}\text { Mytilus } \\
\text { edulis }\end{array}$ & $\begin{array}{l}15 \\
15\end{array}$ & $\begin{array}{l}15 \\
30\end{array}$ & $\begin{array}{l}0.7 \\
0.6\end{array}$ & $\begin{array}{l}25 \\
29\end{array}$ & $\begin{array}{l}31 \\
35\end{array}$ & $\begin{array}{l}81 \\
84\end{array}$ \\
\hline & 1 & $\begin{array}{l}\text { Mytilus } \\
\text { edulis }\end{array}$ & $\begin{array}{l}15 \\
15\end{array}$ & $\begin{array}{l}15 \\
30\end{array}$ & $\begin{array}{l}0.1 \\
0.1\end{array}$ & $\begin{array}{l}20 \\
18\end{array}$ & $\begin{array}{l}22 \\
21\end{array}$ & $\begin{array}{l}81 \\
84\end{array}$ \\
\hline & 2 & $\begin{array}{l}\text { Enchytraeus } \\
\text { albidus }\end{array}$ & 15 & 18 & $0.1-0.2$ & 35 & 70 & 59 \\
\hline \multirow[t]{4}{*}{ N. virens } & 3 & $\begin{array}{c}\text { Lanice } \\
\text { conchilega }\end{array}$ & $8 / 16$ & 20 & $0.5-8.0$ & $35-50$ & & \\
\hline & 4 & $\begin{array}{l}\text { Nephtys } \\
\text { hombergii }\end{array}$ & 15 & & $1.5-4.0$ & 44 & 52 & 85 \\
\hline & 5 & Biodeposits & 20 & & 0.6 & 7 & 29 & \\
\hline & & Clamtissue & 20 & & 0.5 & 23 & 77 & \\
\hline $\begin{array}{l}1 \text { Neuhoff (this study). } \\
2 \text { Ivleva }(1970) . \\
3 \text { Goerke }(1971 \mathrm{~b}) .\end{array}$ & & \multicolumn{7}{|c|}{$\begin{array}{l}4 \text { Kay and Brafield (1973). } \\
5 \text { Tenore and Gopalan (1974). }\end{array}$} \\
\hline
\end{tabular}


$(30 \% \mathrm{~S})$ or remain unaffected $(15 \% \mathrm{~S})$. Compared with $N$. succinea, the reserve and energy contents of $N$. diversicolor are higher at $5{ }^{\circ} \mathrm{C}$. This indicates that $N$. diversicolor is better fitted to low temperature conditions than is $N$. succinea. N. succinea reduces or even ceases feeding at low temperatures. This fact agrees with observations of Mangum (1969) who reported that $N$. succinea from York River Estuary exhibited no feeding response to chemical stimulation at temperatures below $10^{\circ} \mathrm{C}$.

An influence of sal in it $y$ on metabolism is demonstrated by markedly lower amounts of reserves in fed individuals and by higher energy losses of starving worms tested at $30 \% \mathrm{~S}$, compared with those at $15 \% \mathrm{~S}$. This effect may be explained on the basis of the model given by Hochachka and Somero (1973) who discuss a $\mathrm{Na}^{+}$or $\mathrm{Cl}^{-}$induced activation of enzymatic glutamate catalysis as a base for the production of amino acids needed for cell-volume regulations necessary to cope with external salinity increase.

The lower energy loss of Nereis diversicolor during starvation at $15 \% \mathrm{~S}$ in comparison with $N$. succinea indicates a better adaptation of this species to brackish water conditions. At high salinity $(30 \% \mathrm{~S})$ the reverse relation prevailed indicating that $N$. succinea prefers higher salinities.

In summary Nereis virens, the largest species tested here, has by far the fastest and most efficient growth (Goerke, 1971b; Kay and Brafield, 1973). This species tolerates euhaline and oligohaline conditions but prefers habitats with higher salinities (Hartmann-Schroeder, 1971). N. diversicolor from the Baltic Sea combines fast growth and efficient food conversion with an ability to inhabit biotopes with low salinities and temperatures. This omnivorous species is able to grow even at low temperatures. Ivleva (1970) reports that gonads of adult individuals ripen even at $5{ }^{\circ} \mathrm{C}$. Baltic Sea $N$. succinea grow slower and show less efficient food conversion. The salinity range of the detritusfeeding worms is similar to that of $N$. diversicolor. $N$. succinae, however, requires higher temperatures for growth. The ability to live at low salinities and to produce even at low temperatures predestinates $N$. diversicolor for the specific environmental conditions prevailing in the Baltic Sea, including its eastem parts which are rather cold in winter. My results on growth and food conversion in $N$. succinea, however, suggest that this species prefers distinctly higher salinities and temperatures.

Acknowledgement. This study is part of the author's dissertation. I should like to thank Professor $\mathrm{H}$. Theede for suggesting the topic and for advice and comments on the manuscript.

\section{LITERATURE CITED}

Chambers, M. R. and Milne, H. (1975). Life cycle and production of Nereis diversicolor O. F. Müller in the Ythan Estuary, Scotland. Estuar. \& Coast. Mar. Sci, 3, 133-144.

Dales, R. P. (1951). An annual history of a population of Nereis diversicolor O. F. Müller. Biol. Bull mar. biol. Lab., Woods Hole, 101, 131-137.

Gentry Instruments. Assembly and operating instructions for the Phillipson Oxygen Microbomb Calorimeter. Gentry Instruments Inc., 1007 Owens St., Aiken, S.C. 29801 U.S.A.

Goerke, H. (1966). Nahrungsfiltration von Nereis diversicolor O. F. Müller (Nereidae, Polychaeta). Veröff. Inst. Meeresforsch. Bremerh., 10, 49-58.

Goerke, H. (1971a). Die Ernährungsweise der Nereis-Arten (Polychaeta, Nereidae) der deutschen Küsten. Veröf. Inst. Meeresforsch. Bremerh., 13, 1-50.

Goerke, H. (1971b). Nahrungsaufnahme, Nahrungsausnutzung und Wachstum von Nereis virens (Polychaeta, Nereidae). Veröff. Inst. Meeresforsch. Bremerh., 13, 51-78.

Handel, E. van (1965). Estimation of glycogen in small amounts of tissues. Analyt. Biochem., 11, 256-265.

Hartmann-Schroeder, G. (1971). Annelida, Borstenwürmer, Polychaeta. In M. Dahl und F. Peus (Eds), Die Tierwelt Deutschlands, Bd. 58. VEB G. Fischer, Jena. pp. 1-594.

Hochachka, P. W. and Somero, G. N. (1973). Water and solute problems. In P. W Hochachka and G. N. Somero (Eds), Strategies of Biochemical Adaptation. W. B. Saunders, Philadelphia, London, Toronto. pp. 97-143.

Ivleva, I. V (1970). The influence of temperature on the transformation of matter in marine invertebrates. In J. H. Steele (Ed.), Marine Food Chains. Oliver \& Boyd, Edinburgh. pp. 96-112.

Kay, D. G. and Brafield, A. E. (1973). The energy relations of the polychaete Neanthes (= Nereis) virens (Sars). J. Anim. Ecol., 42, 673-692.

Kinne, O. (1954). Über das Schwärmen und die Larvalentwicklung von Nereis succinea Leuckart (Polychaeta). Zool. Anz., 153, 114-126.

Kinne, O. (1964). The effects of temperature and salinity on marine and brackish water animals. II. Salinity and temperature salinity combinations. Oceanogr. mar. Biol., 2, 281-339.

Kinne, O. (1970a). Temperature: animals: invertebrates. In O Kinne (Ed.), Marine Ecology, Vol. I, Environmental Factors, Part 1. Wiley, London. pp. 407-514.

Kinne, O. (Ed) (1970b). Marine Ecology, Vol. I, Environmental Factors, Part 1, Wiley, London.

Kinne, O (1971a). Salinity: animals: invertebrates. In O Kinne (Ed.), Marine Ecology, Vol. I, Environmental Factors, Part 2. Wiley, London. pp. 821-995.

Kinne, O. (Ed.) (1971b). Marine Ecology, Vol. I., Environmental Factors, Part 2. Wiley, London.

Lowry, O. H., Rosebrough, N. J., Farr, A. L. and Randall, R. J. (1951). Protein measurement with the Folin Phenol Reagent. J. biol. Chem., 193, 265-275.

Mangum, C. P. (1969). Low temperature blockage of the feeding response in boreal and temperate zone polychaetes. Chesapeak Sci., 10, 64-65.

Muus, B. J. (1967). The fauna of Danish estuaries and lagoons. Distribution and ecology of dominating species in the shallow reaches of the mesohaline zone. Meddr. Danm. Fisk.- og Havunders., 5, 1-316.

Neuhoff, H.-G. (1977). Experimentelle Untersuchungen zum Stoff- und Energieumsatz von Nereis-Arten (Polychaeta) aus der westlichen Ostsee. Ph. D. thesis, University of Kiel. 
Neuhoff, H.-G. (1979). Effects of seasonally varying factors on a Nereis succinea population (Polychaeta, Annelida). Mar Ecol. Prog. Ser, 1, 263-268.

Phillipson, J. (1964). A miniature bomb calorimeter for small biological samples. Oikos, 15, 130-139

Smith, R. I. (1970). Chloride regulation at low salinities by Nereis diversicolor (Annelida, Polychaeta). I. Uptake and exchange of chloride. J. exp. Biol., 53, 75-92

Tenore, K. R. and Gopalan, U. K. (1974). Feeding efficiencies of the polychaete Nereis virens cultured on hard-clam tissue and oyster detritus. J. Fish. Res. Bd Can., 31. 1675-1678.

Zöllner, N. and Kirsch, K. (1962). Über die quantitative Bestimmung von Lipoiden (Mikromethode) mittels der vielen naturlichen Lipoiden (allen bekannten Plasmalipoiden) gemeinsamen Sulphophosphovanillin Reaktion. Z. ges. exp. Med., 135, 545-561.

This paper was presented by Professor H.-P. Bulnheim; it was accepted for printing on September 18,1979 